\title{
АДМИНИСТРАТИВНАЯ РЕФОРМА
} В РОССИЙСКОЙ ФЕДЕРАЦИИ

\section{В.С. Комаровский}

Если в конце XIX - начале XX столетия политическая наука жестко разграничивала политику и государственно-административное управление, то в настоящее время в центре ее внимания оказались зоны наложения (пересечения) административной и политической деятельности; механизмы, рамки, ограничения, целесообразность и последствия включения бюрократии в политический процесс [см. Комаровский, Сморгунов 2004: 10]. Подобное изменение угла зрения позволяет рассматривать политическую составляющую административной реформы в качестве самостоятельного предмета исследования и использовать при ее анализе теории эволюции политических институтов. Специалисты выделяют три возможных пути трансформации политических институтов:

- непредвиденные обстоятельства порождают прецедент, который становится правилом;

- изменение происходит в форме медленной эволюции, как реакция на меняющуюся ситуацию;

- причиной изменения выступают сознательные стратегические действия агентов политического влияния.

Казалось бы, третий вариант - путь целенаправленных реформ - самый предпочтительный. Однако знания, которыми мы располагаем в настоящее время, не позволяют точно просчитать даже краткосрочные и локальные последствия институциональных изменений и понять, почему институциональные структуры, прекрасно действующие в одних социально-экономических условиях, приводят к катастрофическим результатам в других. Исходя из этого, многие западные специалисты полагают, что при конституционном строительстве необходимо руководствоваться не только и не столько рациональными соображениями, сколько этическими и нормативными представлениями, в частности понятиями "справедливость", “человеческое достоинство”, “моральные принципы” и т.п. [см., напр. Ромстайн 1999]. Данный подход, несомненно, правомерен и по отношению к России, поскольку немалая часть изъянов ее административной системы обусловлена не специфически российскими, а глобальными причинами.

Последние десятилетия ушедшего века со всей очевидностью обнаружили неспособность иерархически организованной системы государственного управления справиться с вызовами новой эпохи. Подобная система, предполагающая многочисленные согласования при принятии решений, не отвечает требованиям современного информационного обще-

КОМАРОВСКИЙ Владимир Савельевич, доктор философских наук, зав.кафедрой политологии Российской академии государственной службы при Президенте РФ. 
ства с его динамизмом, непредсказуемостью и быстрой сменой ситуаций. Не в состоянии она адекватно реагировать и на изменившиеся запросы граждан. Не случайно в конце XX в. в большинстве развитых стран Европы, Америки и Азии начались административные реформы, которые продолжаются до сих пор. Проблемы, на решение которых нацелены эти реформы, в значительной мере совпадают с российскими: слабая эффективность работы административного аппарата, “утечка" лучших кадров в коммерческие структуры, резкое падение доверия граждан к институтам власти и т.д.

Общий вектор реформирования задается новым пониманием природы и функций активизирующегося государства - преврашением его из "верховного правителя" в “менеджера" [Behrens 2001: 92]. Это предполагает переход от модели бюрократии, ориентированной на обслуживание политического руководства страны (хотя эта функция, вне сомнения, сохраняется), своего непосредственного начальства или даже на отстаивание корпоративных и личных интересов чиновников, к так наз. модели “отзывчивой бюрократии” - открытой, прозрачной, ставящей во главу угла интересы граждан, доступной внешнему контролю, рационально организованной, ответственной и пользующейся уважением в обществе. Именно на такую модель, согласно официально опубликованным документам, и ориентировались разработчики российской административной реформы.

Подобная модель бюрократии, безусловно, является идеальной в веберовском смысле. Полностью она не реализована ни в одной стране мира. Ее эвристическое значение состоит в том, что она характеризует желаемое положение вещей и служит эталоном для оценки как реального состояния аппарата, так и конкретных шагов по его реформированию.

Очевидно, что движение в направлении отзывчивой, прозрачной бюрократии требует изменения ценностно-нормативных установок работников аппарата, их представлений о целях и задачах своей деятельности, а также тех принципов, которыми они руководствуются, принимая те или иные решения. В настоящей статье, опираясь на данные мониторинговых исследований, проводившихся в 1997 и 2003 - 2004 гг.*, мы попытаемся проследить, как далеко продвинулась наша страна в плане переориентации аппарата на новую модель функционирования. При этом мы сосредоточим внимание на позиции работников аппарата по отношению к административной реформе и, в первую очередь, к той ее части, которая касается взаимодействия с гражданами. Подобный фокус исследования обусловлен, в частности, тем, что в последние годы возникла реальная угроза превращения аппарата в полностью независимую от общества корпорацию, преследующую сугубо клановые интересы. Более того, как отмечают некоторые исследователи, под влиянием трансформаций, происходящих в других сегментах политической системы, в

\footnotetext{
* Исследование включало в себя экспертный опрос госслужащих среднего звена (на уровне начальника управления) в 15 субъектах РФ, массовый опрос населения (выборка 1500 чел.; в 2004 - контрольный опрос 200 чел.) и проведение фокус-групп.
} 
России возникли реальные предпосылки для формирования неономенклатуры - целостного, замкнутого общественного слоя, контролирующего все рычаги власти и управления [см. Соловьев 2004]. Цементирующей основой этой неономенклатуры, как и в советские времена, может стать верхушка бюрократии.

В концепции реформирования государственной службы России предусмотрены четыре главных направления преобразований: (1) изменение внутриведомственных отношений, (2) изменение межведомственных отношений, (3) изменение отношений по линии аппарат - политическое руководство страны и (4) изменение отношений по линии аппарат - граждане. В данной статье нас будет интересовать главным образом четвертое направление, разумеется, с учетом того, что на развертывающиеся здесь процессы влияют изменения, происходящие в рамках других направлений.

По оценке специалистов, административная реформа в России не принесла желаемых результатов и пока "ничем не отличается от очередной аппаратной перетряски” [Афанасьев 2004: 23]. Не удовлетворены ее ходом и российские граждане. Как показал проведенный в 2003 г. опрос общественного мнения, абсолютное большинство россиян видят в реформе госслужбы чисто аппаратное мероприятие. В настоящее время только $10 \%$ респондентов полностью поддерживают реформу и еще $17429,5 \%$ поддерживают ее отчасти. Уровень поддержки практически не растет. При этом многие считают, что по отдельным показателям, напрямую затрагивающим их интересы, положение дел в госслужбе даже ухудшилось. В первую очередь, это касается административного произвола и нарушения прав граждан. По мнению большинства опрошенных, за годы реформ уровень коррупции не уменьшился, качество административных услуг осталось низким, государственный аппарат не стал более демократичным, не повернулся лицом к гражданам. Не выросло и доверие к чиновникам: в том, что госслужащие реально защищают интересы граждан, в 2003 г. были убеждены лишь 8,3\% респондентов*. Население по-прежнему слабо ориентируется в работе аппарата и плохо информировано о его деятельности. Признавая необходимость реформирования аппарата, россияне в массе своей полагают, что решать эту задачу должно политическое руководство страны [подробнее см. Комаровский 2004].

Посмотрим теперь, как оценивают административную реформу сами госслужащие. В соответствии с программой реформ на $2002-2005$ гг. и Законом "О государственной гражданской службе Российской Федерации” от 27 июля 2004 г. госаппарат должен в равной степени отражать интересы общества и государства. Однако, по оценке работников аппарата, на практике ситуация складывается по-другому (см. табл. 1).

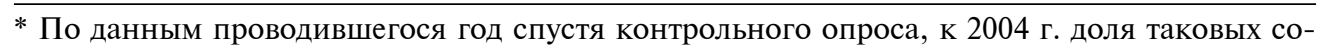
ставила $11 \%$.
} 
Таблица 1

\begin{tabular}{|l|c|c|c|}
\hline $\begin{array}{l}\text { Чьи интересы в первую очередь защищают сегодня } \\
\text { госслужащие?* }\end{array}$ & $\begin{array}{c}\mathbf{1 9 9 7} \\
\text { (в \%) }\end{array}$ & $\begin{array}{c}\mathbf{2 0 0 3} \\
\text { (в \%) }\end{array}$ & $\begin{array}{c}\mathbf{2 0 0 4} \\
\text { (в \%) }\end{array}$ \\
\hline Государства & 20,0 & 60,0 & 58,1 \\
\hline Своего ведомства & 40,0 & 55,5 & 51,0 \\
\hline Граждан & 8,0 & 32,5 & 31,4 \\
\hline Своего начальства & 23,0 & 28,5 & 26,7 \\
\hline Свои собственные & 0 & 24,0 & 19,5 \\
\hline Коммерческих структур & - & 6,5 & 4,3 \\
\hline Другие & 0 & 2,0 & 1,9 \\
\hline
\end{tabular}

* Сумма ответов превышает $100 \%$, так как по методике опроса можно было выбрать несколько вариантов.

Как видно из представленных в табл. 1 данных, за последние годы в аппарате произошли довольно серьезные позитивные перемены. Тем не менее, целый ряд проблем остался нерешенным. В частности, из ответов госслужащих следует, что ведомственные интересы для них более значимы, нежели интересы граждан. По степени приоритетности последние лишь немного превосходят интересы начальства. Важно также отметить, что к 2003 г. ситуация, по сути, “законсервировалась” и наметившаяся в конце 1990-х - начале 2000-х годов динамика сошла на нет. На настоящий момент свыше $63 \%$ госслужащих признают, что в деятельности аппарата интересы людей по-прежнему находятся на заднем плане. Учитывая, что приводимые цифры фиксируют оценку госслужащими их собственной деятельности, правомерно предположить, что в реальности дело обстоит еще хуже.

Конечно, некоторые подвижки в сознании госслужащих, свидетельствующие о росте внимания аппарата к нуждам и запросам граждан, обозначились. Так, в 2004 г. около трети (31\%) опрошенных экспертов сочли оторванность госслужбы от реальных проблем граждан одним из тех недостатков, который необходимо устранить в первую очередь (в 2003 г. такой позиции придерживались $25 \%$ респондентов). К существенным изъянам в функционировании госаппарата были отнесены также низкое качество предоставляемых гражданам услуг $(17,1 \%)$; отсутствие реакции на обращения граждан, волокита, отписки при рассмотрении дел (15\%); закрытость госслужащих для граждан $(10,5 \%)$. Вместе с тем приходится констатировать, что далеко не все госслужащие связывают улучшение работы собственных ведомств с "усилением ориентации на потребности граждан”. Этой точки зрения придерживаются только $18,1 \%$ госслужащих, 15,2\% возлагают надежды на расширение общественного контроля, а $13,3 \%$ - на более тесное сотрудничество с гражданами и их объединениями, тогда как большинство по-прежнему надеется решить накопившиеся проблемы путем совершенствования внутриведомственной деятельности (контроля, отчетности, исполнения) и кадровой политики (56,2\% и $53,3 \%$, соответственно).

При сравнении данных опросов госслужащих и рядовых граждан сразу же бросается в глаза одно важное совпадение: и те и другие считают, 
что административная реформа нацелена прежде всего на улучшение системы внутриведомственных отношений и отношений по линии госслужба государственные органы в целом. И хотя подобные представления противоречат самой концепции реформы, думается, что в практическом плане они во многом справедливы. Как бы то ни было, опрос госслужащих однозначно свидетельствует о том, что с точки зрения удовлетворения запросов населения и качества административных услуг реформа госслужбы пока не дала позитивных результатов.

В ходе упоминавшегося выше опроса населения выяснилось, что россияне, практически не претендуя на непосредственное участие в процессах управления и принятия решений, тем не менее хотели бы видеть административную власть открытой для граждан. В необходимости такой открытости сегодня убеждены и госслужащие. При этом, что показательно, большинство из них склонно искать истоки недостаточной прозрачности госслужбы в ее собственной деятельности (см. табл. 2).

Таблица 2

\begin{tabular}{|l|c|c|}
\hline $\begin{array}{l}\text { Что препятствует открытости и прозрачности государственной } \\
\text { службы?* }\end{array}$ & $\begin{array}{c}\mathbf{2 0 0 3} \\
\text { (в \%) }\end{array}$ & $\begin{array}{c}\mathbf{2 0 0 4} \\
\text { (в \%) }\end{array}$ \\
\hline Негативный исторический опыт и традиции российского чиновничества & 30,5 & 35,2 \\
\hline Нежелание высших чиновников & 37,0 & 34,3 \\
\hline Отсутствие демократических ценностей в сознании ч иновников & 31,0 & 33,3 \\
\hline Пассивность граждан и их объединений & 30,0 & 29,5 \\
\hline Незаинтересованность групп лоббирования (бизнеса, криминала) & 22,0 & 18,1 \\
\hline Отсутствие политической воли у высшего руководства страны & 21,5 & 17,1 \\
\hline Отсутствие материально -технической базы, ф инансирования & 15,5 & 16,2 \\
\hline Другое & 2,5 & 6,2 \\
\hline
\end{tabular}

* Сумма ответов превышает $100 \%$, так как по методике опроса можно было выбрать несколько вариантов. Данные приведены в порядке убывания количества выбравших соответствующий вариант ответа в 2004 г.

Итак, мы видим, что к числу наиболее значимых факторов, препятствующих открытости и прозрачности аппарата, эксперты относят устоявшиеся традиции российской госслужбы, противодействие высших чиновников и отсутствие в сознании чиновничества демократических ценностей. То есть, по мнению самих госслужащих, причины нынешнего положения вещей носят скорее внутренний, чем внешний характер. Следует также констатировать, что большинство из них не считают такую ситуацию нормальной и готовы предложить конкретные меры, которые могли бы способствовать ее изменению.

Что же мешает решению проблемы? Прежде всего - организация работы аппарата. Как отмечали участники фокус-групп, при отсутствии регламентов для абсолютного большинства должностных позиций, ясных критериев оценки работы, четких процедурных правил при принятии решений и лиц, ответственных за их исполнение, обеспечить прозрачность деятельности административных органов заведомо невозможно. Крайне затрудняет движение в этом направлении и недоверие населения к орга- 
нам власти, а аппарата - к гражданам и их объединениями, хотя определенные подвижки здесь уже наметились.

Если в 2003 г. большинство госслужащих объясняли недостаток взаимопонимания между аппаратом и общественными организациями неготовностью последних к конструктивному сотрудничеству с органами власти, амбициями лидеров таких организаций и незрелостью общества, то уже год спустя предлагаемые ими трактовки сложившейся ситуации оказались гораздо более сбалансированными. Доля госслужащих, видящих причины медленного развития отношений между общественными организациями и органами власти в тех или иных аспектах деятельности самих этих организаций, сократилась, причем по ряду позиций весьма существенно. Одновременно, хотя и не очень значительно, выросло число тех, кто возлагает вину за слабый прогресс в указанной сфере на органы власти (см. табл. 3).

таблица 3

\begin{tabular}{|l|c|c|}
\hline $\begin{array}{l}\text { Почему плохо развиваются отношения общественных } \\
\text { организаций с органами власти? }\end{array}$ & $\begin{array}{c}\mathbf{2 0 0 3} \\
\mathbf{( в ~ \% )}\end{array}$ & $\begin{array}{c}\mathbf{2 0 0 4} \\
(\text { в \%) }\end{array}$ \\
\hline Это не нужно органам власти & 10,5 & 14,3 \\
\hline Это не нужно отдельным чиновникам & 18,5 & 10,5 \\
\hline Общественные организации затрудняют деятельность власти & 7,5 & 4,3 \\
\hline Общественные организации не умеют строить отношения с властью & 25,0 & 22,4 \\
\hline Причина в амбициях лидеров общественных организаций & 29,0 & 19,5 \\
\hline Общество в целом еще не созрело для этого & 43,0 & 25,2 \\
\hline Другое & 4,0 & 3,8 \\
\hline
\end{tabular}

Как свидетельствуют приведенные в табл. 3 данные, госслужащие постепенно начинают осознавать тот непреложный факт, что современная система государственного управления не может эффективно функционировать без взаимодействия с гражданами и их ассоциациями, что, только объединив усилия и ресурсы государственных и общественных структур, можно справиться с встающими перед страной проблемами. Подобный поворот госслужащих в сторону общества полностью отвечает тенденциям, набирающим силу в наиболее развитых странах Запада и получившим научное осмысление в теории политических сетей. Согласно этой теории, с переходом к информационной эпохе государство не снимает с себя ответственность за состояние общества, а разделяет ее с заинтересованными в решении той или иной конкретной проблемы общественными структурами. Фактически это означает, что государство делится своими властными полномочиями с общественными организациями.

Правда, бо́льшая часть российских госслужащих пока не верит в то, что общественные организации способны стать полноценными партнерами государства в управленческом процессе. Тем не менее, сдвиги в этом направлении есть, и довольно заметные. Главный сдвиг: уменьшилось число принципиальных противников партнерских отношений властных и общественных структур в процессе управления при одновременном увеличении (в 1,5 раза) числа убежденных в том, что общественные органи- 
зации могут взять на себя часть ответственности за состояние дел в стране (см. табл. 4). Показательно, что доля последних примерно совпадает с долей тех, кто признает необходимость расширения общественного контроля над деятельностью аппарата и видит в подобном контроле важный резерв укрепления государственной службы в России.

Таблица 4

\begin{tabular}{|l|c|c|}
\hline $\begin{array}{l}\text { Способны ли общественные организации взять на себя часть } \\
\text { функций органов власти? }\end{array}$ & $\begin{array}{c}\mathbf{2 0 0 3} \\
\text { (в \%) }\end{array}$ & $\begin{array}{c}\mathbf{2 0 0 4} \\
\text { (в \%) }\end{array}$ \\
\hline В целом способны & 9,5 & 15,2 \\
\hline В основном не способны & 40,5 & 42,9 \\
\hline Они не должны этого делать & 49,0 & 40,0 \\
\hline Другое & 1,0 & 1,9 \\
\hline
\end{tabular}

Итак, совокупность полученных в ходе исследования данных позволяет заключить, что в настоящее время за усиление демократических начал в работе аппарата, за тесное, деловое сотрудничество с гражданами и их объединениями выступают порядка 15-20\% госслужащих. С учетом того, что значительная часть самих граждан пока не готова к конструктивному взаимодействию с органами власти, появление в аппарате столь весомой доли демократично, новаторски настроенных лиц следует оценить как весьма важный результат административной реформы. Более того, при сохранении нынешних темпов роста их численности можно надеяться, что реформа внесет заметный вклад в решение извечной российской проблемы, связанной с отстраненностью общества от управления собственными делами и взаимным недоверием власти и граждан.

Вместе с тем было бы неверным полагать, что озабоченность ряда исследователей перспективой формирования в России “неономенклатуры” не имеет под собой оснований. В настоящее время соответствующие тенденции наблюдаются лишь на верхних ступенях управленческой иерархии, но, закрепившись там, они могут захватить и среднее управленческое звено, перечеркнув зафиксированные нами позитивные сдвиги.

Афанасьев М. 2004. Негодная формула управления. - Политический журнал, № 76.

Комаровский В.С. 2004. Реформа государственной службы России: ожидания и требования граждан. - Социология власти, № 5.

Комаровский В.С., Сморгунов Л.В. (ред.) 2004. Политико-административное управление. М.

Ромстайн Б. 1999. Политические институты: общие проблемы. - Гудин Р., Клингеман Х.-Д. (ред.) Политическая наука: новые направления. М.

Соловьев А.И. 2004. Технологии администрирования: политические резонансы в системе власти современной России. - Полис, № 6.

Behrens F. 2001. Verwaltungsreform des Landes Nordrhein-Westfalen. - Gunther A. (Hrsg.) Verwaltungsmodernisierung. Baden-Baden. 